\title{
INTERACTIONS IN CONVERSATIONS BETWEEN THREE PEOPLE IN PODCAST: A STUDY OF PRAGMATICS
}

\author{
Ricka Putri Suteja \\ Universitas Indonesia (UI), Depok, Indonesia \\ E-mail: ricka.putri01@ui.ac.id
}

Received: 2021-11-08

Accepted: 2021-11-27

\begin{abstract}
The interaction process between each party can affect the course of the conversation. This study aims to investigate the characteristics of podcast conversations and the communication style used between two interviewers and one resource person in Catatan Psikologi's podcast entitled Quarter Life Crisis. This study used qualitative methods with a conversational analysis (CA) approach as well as collaborative communication and competitive communication theories. The process of conversations transcription used the conventions written by Du Bois. The results showed minimal response phenomena, interruptions, and overlaps in the conversation, leading to collaborative communication both at the word and sentence. However, the collaborative communication style has a more significant emergence. Based on the analysis above, the parties involved in the communication tried to build togetherness and cooperation which can be seen in the narrative. When one speaker told a story, the others also participated in the conversation by providing minimal responses, showing sympathy, and also comments or opinions.
\end{abstract}

Keywords: podcast, conversation analysis, collaborative communication, competitive communication

\section{Introduction}

Previously, people would interact and communicate with someone who is quite far away by writing through letters. However, the emergence of the internet for the first time in the world in 1969 which was initiated by ARPA (Rustendi, 2018: 3) and can be enjoyed by everyone until now, could break these barriers. Currently, people can communicate wherever they are, no exception in remote areas as long as they have an internet network.

Communication provides the power to fulfil human needs which cannot be separated from its nature as social beings. Panuju (2018: vi) in the preface of book "Communication Studies", mentioned that people start to communicate since they exist in a mother's womb until death. In fact, communication is very important to promote something, convince something, tell something, and so on. This principle also brings new trends in modern communication. Interaction in communication is no longer limited as a meeting between (at least) two humans (Wilkinson, 2019) to convey a message, but because humans also have affective needs to be fulfilled (Coupé et al, 2019) and also increase self-existence.

This can be observed with the emergence of various communication interactions from various parties which were recorded and uploaded to the digital world. One of them is podcasts, which have become quite popular in Indonesia recently. Podcast is an acronym for 
iPod-Broadcasting which refers to the Apple iPod device as the first podcast distribution platform (Bonini, 2015). In simple terms, podcasts can be interpreted as audio files uploaded on the internet, and available on demand (listeners might potentially listen at any time and choose any topic). This file can be downloaded or directly played on each device.

The special characteristic of this podcast, coupled with the increasing number of people who create podcasts, made me interested in researching the conversations in podcasts. I chose a podcast with a theme that was quite interested for teenagers and young adults. This podcast was created by the Institute for Psychological Records with the title Quarter Life Crisis. This podcast was first uploaded on March 20, 2019. There were two questions that were discussed in this study: (a) What are the characteristics of conversations that occur among a group of people, especially in terms of how they build conversations. (b) What are the collaborative and competitive communication styles that occur in conversations.

The interesting thing regarding the emergence of various kinds of podcasts is the conversational style of each participant. In podcasts we could not see the participants' expression, therefore, the research was only focused on the results of the conversation transcription.

\section{Literature Review}

Initially, this study used conversation analysis. According to Schegloff (in GonzalezLloret, 2011: 309), "Conversation Analysis (CA) studies of speaking practices across languages and cultures can provide a basis for comparison of L2, or language learner, speaking practices with L1 speaker norms in both L1 and L2." Kasper (2006: 285) conveys that "Conversation Analysis (CA) has accrued by far the largest and most coherent cumulative body of research, lending high credibility to its theoretical foundations and methodology. CA therefore recommends itself not only as a lens for critical scrutiny of speech act research but provides a well-documented alternative."

Based on both statements above, it can be concluded that Conversation Analysis is a good alternative theory for researching conversations. Conversational analysis tries to observe that utterances in conversational interactions are not single events, but have interdependencies.

The second theory is Collaborative Communication and Competitive Communication theory. Collaborative Communication or collaborative communication is a communication style that is cooperative and helps each other in conversation. In collaborative communication, each party will not feel that his ideas and phrase are useless (Coates, 2015), which are usually indicated by minimal responses such as "yeah", "mhm" (Albaqami 2017: 6612).

Competitive Communication covers a competitive style that is considered more assertive and dominating. This type of communication might occur when a speaker interrupts another speaker's (Ersoy, 2008: 9). There are three factors that can affect collaborative communication and competitive communication as mentioned above, namely (a) minimal response, (b) interruption, (c) overlap (Ersoy, 2008: 10-16).

In a study conducted by Tannen (2005), he recorded a conversation session during a dinner between him and his five friends. The objective of this study is to analyze the conversational style of each participant. One thing that needs to be considered is the meaning of the words. It is also necessary to know the emotion of speaker whether he was angry, sad, happy, and so on. A similar study conducted by Guritno (2008) investigated the conversations of three women who speak bilingual and grown in several countries other 
than Indonesia by recording the conversation between the researcher and two of his friends. The purpose of this research is to investigate the way of these three people in building and maintaining interaction by studying the characteristics of their conversation. The interesting thing is in the conversation there was cooperation in building speech, overlapping utterances, minimal responses and laughter, as well as partial and complete repetition of utterances.

Another research about Communication Analysis was also conducted by Wardhani (2016). Wardhani analyzed humour that occurs in conversations on talk shows that are often brought up by Late Show host, John Oliver. In this study, the researcher found that the four conversational actors had alternating roles, both as speakers and interlocutors. In addition, a pattern of humour was also found in the conversation. The pattern that usually generated is when someone asked a question or statement, then it must be responded to and closed by laughter. This indicates that in every conversation, it is very important for each speech partner to understand the context of conversation. So that, we can also conclude that the interaction process between each party can affect the course of the conversation. All studies above show that a conversational analysis and collaborative communication is needed in order to analyze a conversation thoroughly.

Based on the review of researcher, there is no previous research that discusses conversational research on podcasts by utilizing conversational analysis. Conversation analysis is often used on live conversations studies, but this research focused in pragmatics on conversations between speakers in podcasts. In addition, there was limited research that discussed about conversation in Indonesia. For this reason, the researcher decided to conduct a study on the conversations that occur on podcasts. It is expected that this research can provide contribution to conversational analysis, especially conversational analysis on podcasts.

\section{Research Method}

This study used qualitative research methods in order to investigate the conversations of people in a podcast. The qualitative method is considered to be the suitable method for this research because it can assess the condition of objects naturally and can also find out a deeper potency from a data (Sugiyono, 2016). Moreover, this method is able to reveal and understand the possibility of speakers to mention certain speech and the meaning behind them (Guritno, 2008: 48).

This research was analysed further using Conversation Analysis (CA). Conversation analysis is an approach that studies social interactions in order to investigate further about how the actions and speech of each individual can affect the conversational framework in people interaction (Heritage in Guritno, 2008).

Meanwhile, the data was collected with an unstructured observation technique. This method allows researchers to observe the necessary parts, record interesting things, as well as analyse and make conclusions (Sugiyono, 2016). Sugiyono (2016: 229) further stated that this technique requires a space component (the location where situation take places), actors (person who play a role), and activity (action played by actors). It is expected that this research analysis can provide useful explanations to understand the conversation in podcasts.

A transcription system with the conventions of Du Bois (Tian, Jimarkon, \& Singhasiri, 2011)) was used in the preparation process of transcription. However, the researcher did not use the entire existing symbols. The researcher only used certain symbols that related to the 
object that was studied. The symbols used in the transcription of IB, SH, and KJ conversations according to the Du Bois (Tian, et al., 2011) convention are:

\begin{tabular}{|l|l|}
\hline Symbol & Meaning \\
\hline IB & Ibnu \\
\hline SH & Shifa \\
\hline KJ & Kang Jay \\
\hline PP & Podcast Listeners \\
\hline.. & Short pause $(<150$ milliseconds) \\
\hline$\ldots$ & Long Pause ( $>150$ milliseconds) \\
\hline$@$ & Laughter \\
\hline$@$ you're @... & Laughter accompanied by talking \\
\hline$\# \# \#$ & Uncapturable words (one \# symbol per syllable) \\
\hline$\#$ word & Unclear word \\
\hline$[\quad]$ & Overlap (speech that overlaps the first part) \\
\hline$[2 \quad]$ & Overlap (words that overlap the second part) \\
\hline$(($ WORDS)) & Researcher comments \\
\hline$(($ CHUCKLE) & Vocalism (sound) chuckle \\
\hline. & Termination \\
\hline, & Continuity \\
\hline$?$ & Question \\
\hline- & Word cutting \\
\hline$:$ & Elongation \\
\hline$=$ & Latching (no pause between turns of two speakers) \\
\hline$[\ldots .]$. & Conversation cut-off \\
\hline[ & Connecting line between utterances \\
\hline Capital initial & Start a sentence with a capital letter \\
\hline & \\
\hline
\end{tabular}

\section{Results and Discussion}

The researcher analysed the conversations between actors who were involved in the interview: IB, SH, and KJ on the Catatan Psikologi podcast with the title Quarter Life Crisis. This analysis is used to find out how the three conversational actors can build and maintain interactions by studying the characteristics of their conversations. In the conversation, these three parties have different contributions. SH and IB acted as presenters, therefore, their dialogues were dominated by questions addressed to the guest star (KJ). Meanwhile, KJ, based on the data, was known as a guest star, talked more and provided information according to the questions asked by $\mathrm{SH}$ and IB.

The data that was obtained shows that IB, SH, and KJ had an alternate role as speakers as well as addressees. This can be seen in the below conversation.

[...]

(1) $\mathrm{SH}$; Apa sih dari sisi psikologinya si? How about the psychology point of view?

(2) IB; Dari sisi psikologinya wajar gak si quarter life crisis sebenernya? Does the quarter life crisis really reasonable from a psychological point of view?

(3) KJ; Oke, jadi kalo misal kita bedah dari kata per kata yah. OK, so for example we go through word for word.

$[\ldots]$ 
When SH asked (1) Apa sih dari sisi psikologinya si? How about the psychological point of view? It means that SH was a speaker. IB and KJ were interlocutors. On the other hand, when IB asked (2) Dari sisi psikologinya wajar gak si quarter life crisis sebenernya? Does the quarter life crisis really reasonable from a psychological point of view, it shows that IB was a speaker, while $\mathrm{SH}$ and $\mathrm{KJ}$ acted as interlocutors. Similar things can be found in the following statement (3) Oke, jadi kalo misal kita bedah dari kata per kata yah. OK, so for example we go through word for word. In this utterance, KJ acts as a speaker, while IB and SH act as interlocutors.

The dialogue between $\mathrm{SH}, \mathrm{IB}$, and $\mathrm{KJ}$ resulted in a good conversation. This can be seen from the interactions in each utterance. When $\mathrm{SH}, \mathrm{IB}$, and $\mathrm{KJ}$ become speakers they not only convey questions and answers, but also pay attention to common ground so that each other can understand the speaker's intentions and can produce conversations that can be understood by each interlocutor. The similar culture between them, were identified by the similarity in the area where they live, namely in Indonesia and they both use the casual Indonesian language, which is considered to be able to further enlarge the common ground between them. The importance of the awareness of each speaker was to formulate the shared knowledge possessed by the interlocutors, have the opportunity to induce the interlocutors gained the meaning correctly.

However, there are some factors that affect the dialogue in conversation, namely collaborative communication and competitive communication as mentioned above. These factors are (a) minimal response, (b) interruption, (c) overlap.

\subsection{Minimal response}

The minimal response is a support for the speaker from the interlocutor. This response can be expressed verbally, such as $\mathrm{mm}, \mathrm{mhm}$, ah, owh, yes, of course, agree, right, okay or non-verbally, such as nodding, smiling, laughing. These responses are spoken to signal engagement with the speaker. The minimal response is very important as a signal for the active participation of both parties. Minimal responses were also found in the data studied. This can be seen in the following conversation.

$[\ldots]$

(25) KJ; Nah, jadi karena remaja ke dewasa nih kadang labil nih.

So, because the transition phase from teenagers to adults are sometimes unstable

(26) Suka berubah-ubah, maka masuklah berupa tekanan-tekanan dari luar yang menyebabkan dia bingung dengan dirinya sendiri.

They are easily changed, then external pressures enter their life that cause them to be confused with themselves.

(27) $\mathrm{SH}$; [Owh:]

Oh.

(28) IB; [Owh:]

Oh.

$[\ldots]$

The statement from KJ (25) Nah, jadi karena remaja ke dewasa nih kadang labil nih. So, because the transition phase from teenagers to adults are sometimes unstable, (26) Suka berubah-ubah, maka masuklah berupa tekanan-tekanan dari luar yang menyebabkan dia bingung dengan dirinya sendiri. They are easily changed, then external pressures enter their life that cause them to be confused with themselves. This sentece is intended to provide 
information. The statement got a very short response by SH and IB (27) and (28) Owh Oh. The response given by $\mathrm{SH}$ and $\mathrm{IB}$ is one of the minimum response expressions commonly used by Indonesians. The response in the context of the conversation above can be interpreted that $\mathrm{SH}$ and IB have understood on KJ's intention.

In the next part of the conversation, it was found the minimum response given by the speaker was found.

[...]

(59) KJ; Jadi ada dua faktor yah internal dan eksternal.

So there are two factors, internal and external.

(60) Nah jadi kalo temen-temen memasuki masa-masa dua puluhan tahun keatas kayaknya harus memperhatikan dua faktor itu deh.

So if you are entering your twenties and above, it seems that you have to pay attention to those two factors.

(61) Gitu. I see.

I see

(62) IB; [Oh, gitu. Oh I see.

Oh I see.

(63) $\mathrm{SH}$; Kalau tanda-tandanya ada gak si mas?

Is there any signs, sir?

(64) Misalnya kita lagi quarter life crisis itu apa aja si ciri-cirinya?

For example, what are the characteristics if we are in a quarter life crisis?

(65) IB; [lya, iya.

Yes yes

(66) KJ; Nah kalo kita yang parah ya yang ekstrim ya tanda-tandanya itu bisa berujung pada sampe depresi,

Well if we are severe, the extreme signs can lead to depression

$[\ldots]$

In the conversation above, the first speaker KJ gave information (59) Jadi ada dua faktor yah internal dan eksternal. So there are two factors, internal and external. (60) Nah jadi kalo temen-temen memasuki masa-masa dua puluhan tahun keatas kayaknya harus memperhatikan dua faktor itu deh. So if you are entering your twenties and above, it seems you have to pay attention to those two factors. (61) Gitu. I see. I see. IB responded to KJ's speech by giving a minimal response (62) Oh, gitu. Oh I see. Oh, I see. The response from IB is a signal to the speaker who was providing $\mathrm{KJ}$ information that he is listening and understands the speaker's intent. However, SH responded to KJ differently.

SH responded to KJ's by asking a follow-up question (63) Kalau tanda-tandanya ada gak si mas? What are the signs, sir?' (64) Misalnya kita lagi quarter life crisis itu apa aja si ciricirinya? For example, if we are having a quarter life crisis, what are the characteristics?. After the question from $\mathrm{SH}$ was finished, IB immediately gave a minimal response by responding (65) Iya, iya. Yes, yes. IB's intention in responding by using this utterance was not only to show good character as a listener for both of them, but also to show that he was enthusiastic. With the question posed by $\mathrm{SH}$, it is possible that IB also has the same question as $\mathrm{SH}$, but $\mathrm{SH}$ first asked the question.

The minimal response in the conversation above has a function so that the speaker feels comfortable knowing that his conversation is being responded to by the interlocutor, on the 
other hand the interlocutor also has a need to emphasize that he is a good listener and wants to listen carefully.

\subsection{Interruption}

Coates (2015) defines an interrupt as a situation in which the next speaker has started speaking while the first speaker is still speaking. Interruptions are a violation of the rules of conversation and are described as uncooperative, especially to the interlocutor. The style of speech that is often found with interruptions can be seen as a speaker who is aggressive, dominant, and has high competitiveness. According to Khan, Qadir, \& Aftab (2019: 9) there are two types of interruptions, namely the reason that causes the sentence to be cut off, the previous speaker hasn't finished the sentences and the next speaker has started when the new speaker just started his sentence.

The researcher also found interruptions in the conversation data between IB, SH and KJ. This can be seen in the following conversation:

$[\ldots]$

(68) $\mathrm{SH}$; Owh; parah juga yah

Oh, too bad.

(69) KJ; [Itu yang eksrimnya si. Tapi kalo misal yang sederhana yang simple-simpel kita mengalami quarter life crisis itu sudah kita ketahui dengan cara.

That's the extreme one. But if it's a simple, when we experienced a quarter life crisis, we already know how to do it by.

(70) Ada satu momen kita bertanya kepada diri kita, kita ini siapa yah sebenarnya?

There is a moment when we ask ourselves, who am I?

(71) $\mathrm{SH} ; \quad$ [who am I?

who am I?

$[\ldots]$

In the except above, there are two interruptions, where the next speaker speaks right after the previous speaker finishes. The first interruption is found in the statement from KJ (69) Itu yang eksrimnya si. Tapi kalo misal yang sederhana yang simple-simpel kita mengalami quarter life crisis itu sudah kita ketahui dengan cara. That's the extreme one. But if it's simple, when we experienced a quarter life crisis, we already know how to do It by...(70) Ada satu momen kita bertanya kepada diri kita, kita ini siapa yah sebenarnya? There is a moment when we ask ourselves, who am I? The interruption from KJ also implied a message that $\mathrm{KJ}$ as the informant was happy with $\mathrm{SH}^{\prime}$ s response which implies that $\mathrm{SH}$ understood with had been informed earlier by KJ.

This can explain why there was no pause in the statement from $\mathrm{KJ}$ towards the previous statement from $\mathrm{SH}$. The second interruption in this conversation is in the statement spoken by SH (71) who am I? The interruption spoken by SH can be interpreted as that SH was very interested with the statement that had been mentioned earlier from KJ. Thus, when he has an appropriate idea, he immediately wants to throw it out. This is also the reason for the absence of a pause in the dialogue between $\mathrm{SH}$ and $\mathrm{KJ}$.

The following excepts of the conversation also show that there were interruptions in some of his utterances.

$[\ldots]$

(86) IB; Owh jadi tergantung masing-masing orang yah. Ada yang quarter life crisisnya sebentar ada yang lama. 
Oh, so it depends on each person. Some have a short quarter life crisis, some take a long time.

(87) Owh gitu.

Oh I see.

(87) $\mathrm{KJ}$; [betul sekali.

That's right.

(88) IB; Terus kalo menurut kang Jay.

Then, what do you think, Bro Jay?

(89) $\mathrm{KJ} ;$ [Oke..]

Okay..

(90) IB; [Solusinya nih gimana si untuk teman-teman milenial ini mengatasinya ini? So, what is the solution for these millennial deal with this situation?

$[\ldots]$

This conversation also has two interruptions, the first by KJ on (87) betul sekali. 'that's right' and the second by IB Solusinya nih gimana si untuk teman-teman milenial ini mengatasinya ini? 'So, what is the solution for these millennials to deal with this situation?' $\mathrm{KJ}$ conveyed the first utterance right after IB showed a minimal response utterance that symbolized the message that he had understood the meaning. Meanwhile, IB was asking because he was interested in that statement, so the idea of the spontaneous question caused no pause with the previous speech. Interruptions are part of individual habits, one of which is influenced by how the person was raised in a family environment. Interrupts have a complex characteristic. Many people feel that someone who is older or more respected has the right to interrupt, but that depends on the individual. For some of the examples we found above, it can be seen that the interrupted party does not object to the presence of other speakers who interrupt. The conversation data also did not find any interruptions that interfered with the conversation.

\subsection{Overlapping}

Another phenomenon found in podcast conversations between IB, $\mathrm{SH}$, and $\mathrm{KJ}$ was the overlapping phenomenon. According to Coates (2015), overlap can be observed if two or more people speak the almost similar statement, with a small time difference. This phenomenon does not always indicate the same words, it can also with the same meaning, other words for similar or the same expressions or paraphrasing other phrases. However, it is also possible that the overlapping statements, convey different statements in the same theme (Coates, 2015: 113-116).

The researchers also found overlapping in the conversational data between IB, SH and $\mathrm{KJ}$. This can be seen in the following conversation

$[\ldots]$

(3) IB; Mas Jay, eh bukan-bukan, bukan Mas Jay, Kang Jay: Bro Jay, oh no, not Bro Jay, Bro Jay

(4) KJ; [Bro Jay..] Bro Jay

(5) $\mathrm{SH}$; [Bro Jay..] Bro Jay

(6) IB; lya.. [Kang Jay]. Say hi dulu dong Kang Jay.. Yes.. [Bro Jay]. Say hi, Bro Jay.. 


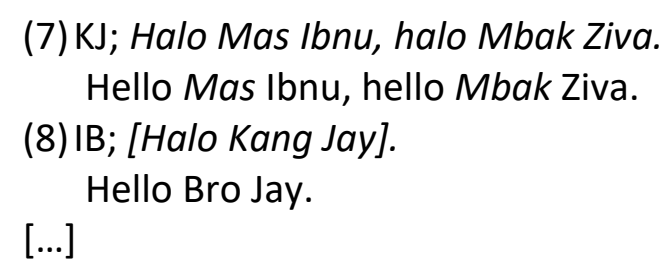

The conversation snippet above has a function as a podcast opener. There are 4 overlapping utterances. KJ and SH both of them said (4) \& (5) Kang Jay. Bro Jay. The overlapping statement at the beginning which was intended to greet guest stars is quite common. This utterance serves to show enthusiasm for the presence of guest stars. The interesting thing is that $\mathrm{KJ}$ mentioned his own name, it can be considered that $\mathrm{KJ}$ as a guest star was not reluctant and he was happy. The overlapping speech at the beginning of the conversation is considered not to disturb the next speaker, because the next speaker, IB, can continue his statement. The one who said (6) 'Iya. Kang Jay. Say hi dulu dong Kang Jay'. Yes. [Bro Jay]. Say hi, Bro Jay. There is also an overlapping speech at the end of the conversation which is spoken by IB on (8) Halo Kang Jay. Hello Bro Jay. It can also be concluded that IB as one of the presenters wants to be polite by greeting the guest stars. This causes the statement to overlap with the previous speaker. The next snippet of conversation was also found to be overlapping as follows:

[...]

(50) KJ; Setelah dapet kerja ditanyain lagi, After getting a job, people will ask again

(51) IB; = kapan nikah? when are you getting married?

(52) KJ; kapan nikah? Setelah nikah kita ditanyain lagi kapan punya anak, gitu kan? When are you getting married? After marriage, we are asked again when we have children, right?

(53) IB; = gitu terus. and so on.

(54) SH; [kapan mati?]. Gak ada pertanyaannya yah. @@@ When will you die. There's no question about that.

(55) KJ; [@@]lya, kapan mati. Yeah, when will you die.

(56) IB; [Gak ada yah], gak ada yang nanya gitu yah. Setelah punya anak kapan mati @@@.

No, no, no one asked that. After having children when will you die?

(57) KJ; Kapan mati. Kita bales dengan pertanyaan kayak gitu aja yah seharusnya. ((CHUCKLE)

"When will you die. It's better to reply them with questions, right?"

Conversation from [50] - [57] can be defined as dialogues that signifies a time sequence. This is indicated by the presence of the word 'after' in the utterances [50], [52], and [54] but the word 'after' has an omission. The jokes that are built are based on common ground, especially among teenagers to young adults who often get questions about going to college, when to work, when to get married, when to have children, and so on. But the question was added by a joke by SH on (54) Kapan mati. When will you die. 
In the dialogue there is a question kapan mati when will you die which overlaps with the previous statement. The speech phenomenon (54) kapan mati when will you die, seems to convey the anxiety and annoyance caused by too many questions addressed to teenagers and young adults, but still ends with laughter. The overlapping speech is also seen in the next speech (55) Hahaha. Iya, kapan mati. Hahaha. Yes, when will you die? Overlapping laughter is a natural thing to happen in conversation. Laughter can have a variety of purposes. However, in the context above, the laughter that occurs has the intention that the previous utterances are funny which cause the speaker KJ to laugh. The statement from IB [56] Gak ada yah, gak ada yang nanya gitu yah. Setelah punya anak kapan mati. Hahaha. No, no, no one asked that. After having children when do you die, shows that as a presenter it is necessary to clarify to the other interlocutors that this is just a joke and not a real question that needs to be asked. The urgency of the clarification that IB wanted to convey as the host, caused him to say it quickly which led to an overlapping phenomenon of the statement delivered by IB.

Each overlapping phenomenon has the potential to violate the next speaker to speak. However, there were no sentences that were not finished due to this phenomenon in this podcast. The overlapping does not only occur at the beginning of the sentence, but can occur in the middle or the end of the sentence. The overlapping phenomena that have been analysed above have various effects. However, the researchers found that overlap in podcast conversations between IB, $\mathrm{SH}$, and $\mathrm{KJ}$ was included in collaborative communication because they showed successful collaboration between speakers. Cooperation is considered successful and cooperative if the speaker who did the overlap includes encouraging words or elaboration on the topic instead of complete sentences with different subjects.

\section{Conclusion}

This study investigates collaborative communication and competitive communication in podcast conversation data, between three parties, IB, SH, and KJ. Based on the results of conversational analysis, it was found that the factors that could influence collaborative communication and competitive communication, namely minimal responses, interruptions, and overlaps, were present in the research data, both at the word and sentence structure. However, the collaborative communication style has a more significant emergence. Based on the analysis above, the parties involved in the communication tried to build togetherness and cooperation which can be seen in the narrative. When one speaker told a story, the others also participated in the conversation by providing minimal responses, showing sympathy, and also comments or opinions. Thus, it can be concluded that in this podcast conversation, a collaborative communication style gets a higher priority than a competitive communication.

\section{References}

Albaqami, Saad Eid. (2017). How Grasping Gender-Related Aspects of Speech is Increased by Multi-Modal Text Analysis-A Case Study. Asian Journal of Science and Technology, 8(11), 6611-6614.

Bonini, T. (2015). The 'Second Age' of Podcasting: reframing Podcasting as a New Digital Mass Medium. Quaderns Del CAC, 4 (7), pp. 21-30.

Coates, J. (2015). Women, Men and Language: A Sociolinguistic Account of Gender $\begin{array}{llll}\text { Differences in } \quad \text { Language } & \text { Routledge. }\end{array}$ https://doi.org/10.4324/9781315645612 
Coupé, C., Oh, Y. M., Dediu, D., \& Pellegrino, F. (2019). Different languages, similar encoding efficiency: Comparable information rates across the human communicative niche. Science advances, 5(9), doi: $10.1126 /$ sciadv.aaw2594.

Ersoy, Selma. (2008). Men compete, women collaborate: a study on collaborative vs competitive communication styles in mixed-sex conversations. Kristianstad University, Sweden: Diva Digital Publishing.

Gonzalez-Lloret, M. (2011). Conversation Analysis of computer-mediated communication. CALICO Journal, 28(2), 308-325.

Guritno, Maria. (2008). Analisis Percakapan Tiga Sahabat Wanita Bilingual di Jakarta. Unpublished Master's Thesis. Universitas Indonesa, Depok.

IImi, Jainal., Ibnu., Shifa. (2019). Catatan Psikologi: Quarter Life Crisis [Podcast]. Malang, Indonesia. Retrieved from: https://open.spotify.com/episode/3YSOntXYraaPOOPKX3Jvdc?si=3Rx0XJ9sT6iDQ9PA v2foMA\&utm_source=copy-link

Kasper, G. (2006). Speech acts in interaction: Towards discursive pragmatics. Pragmatics and language learning, 11.

Khan, S. A., Qadir, S. A., \& Aftab, R. (2019). Managing Agenda Setting in Pakistani Political Talk-Shows: A Functional Analysis of Interruptions. Global Regional Review, 4(1), 4354.

Panuju, Redi. (2018). Pengantar Studi (IImu) Komunikasi. Jakarta, Indonesia: Penerbit Kencana.

Rustendi, Tendi. (2018). Mengenal dan Memanfaatkan Internet. Bandung, Indonesia: PT Sarana Pancakarya Nusa.

Sugiyono. (2016). Metode Penelitian Kuantitatif, Kualitatif dan R\&D. Bandung, Indonesia: Penerbit Alfabeta Bandung.

Tannen, Deborah. (2005). Conversational Style, Analyzing Talk Among Friends. Ed, New. Oxford: Oxford University Press.

Tian, W., Jimarkon, P., \& Singhasiri, W. (2011). Designing a transcription system for face-toface PhD supervisory discourse: A selective-specificity model. In Oral presentation and proceeding at Doing Research in Applied Linguistics International Conference, Thailand.

Wardhani, Meidita. (2016). Pemicu Tawa dalam Gelar Wicara Late Show with David Letterman: Sebuah Analisis Percakapan Humor. Unpublished Master's Thesis. Universitas Indonesa, Depok.

Wilkinson, Ray. (2019). Atypical Interaction: Conversation Analysis and Communicative Impairments, Research on Language and Social Interaction, 52:3, 281299, doi: 10.1080/08351813.2019.1631045 